\title{
Editorial
}

\section{Médico y Paciente: Las enseñanzas de la COVID-19}

\author{
Santiago Moreno Guillén \\ Servicio de Enfermedades Infecciosas, Hospital U. Ramón y Cajal; Departamento de Medicina y \\ Especialidades Médicas, Universidad de Alcalá; smguillen@salud.madrid.org
}

DOI: https://doi.org/10.37536/RIECS.2020.5.1.215

Cuando la OMS informó de un agrupamiento de casos de neumonía en Wuhan, Hubei, China, el 31 de diciembre de 2019, seguramente muy pocos, si es que alguien, podía alcanzar a ver las enormes consecuencias de la nueva enfermedad. Tampoco la identificación de un nuevo coronavirus como agente causal de este síndrome respiratorio parecía añadir gravedad ni mayor alarma. El antecedente de dos coronavirus produciendo enfermedad respiratoria invasiva ponía de manifiesto que, a pesar de una contagiosidad moderada y una letalidad alta, las epidemias que causaron y afectaron a múltiples países del mundo se pudieron controlar con las medidas adoptadas. Parecía haber motivo para entender que tampoco esta vez la situación tendría que ser diferente ni más grave.

Desgraciadamente la evolución de la pandemia no ha sido la que se esperaba. El impacto sanitario ha sido extraordinario, obligando a los países a generar recursos e improvisar medicina de campaña y medidas de contención de la transmisión. El número de personas afectadas y fallecidas a causa de la COVID-19 ha sido enorme y ha traído a la memoria, también por este motivo, la ya lejana pandemia de gripe de 1918. Como dato importante, un porcentaje elevado de los afectados ha sido personal sanitario, que ha prestado un servicio impecable sin eludir responsabilidad ni escatimar dedicación ni esfuerzo.

Yo he tenido el privilegio de vivir la experiencia de la pandemia de COVID-19 desde una doble perspectiva, como médico y como paciente. Como especialista en enfermedades infecciosas, me he sentido implicado en la evolución de la enfermedad desde el primer día y pude colaborar en la atención a los pacientes en mi lugar de trabajo, hasta que la propia enfermedad me retiró del frente. El 14 de marzo tenía un resultado positivo de la PCR para SARS-CoV-2, el 20 de marzo era hospitalizado por mala evolución de la enfermedad y el 21 era transferido a una Unidad de Críticos. Los cuidados excelentes de mis compañeros me devolvieron a la planta de Enfermedades Infecciosas el 27 de marzo y de allí pude ser dado de alta dos semanas más tarde.

Hablo de privilegio porque esta condición de paciente-médico me ha aportado notables enseñanzas. Todos hemos aprendido, y seguimos aprendiendo, como médicos, como personal sanitario, con esta enfermedad extraordinaria. Hemos identificado los síntomas múltiples de una enfermedad desconocida contribuyendo a su descripción, hemos aprendido a sospechar y diagnosticar un nuevo agente infeccioso y hemos improvisado tratamientos imposibles. Aún más, nos hemos familiarizado con métodos para contener la expansión de una enfermedad y hemos aprendido a ser rigurosos con las medidas de aislamiento y distanciamiento social que nos hemos impuesto.

Con toda la importancia de estos conocimientos adquiridos sobre una nueva enfermedad infecciosa, la experiencia como paciente gravemente afectado es seguramente la que me ha proporcionado mayores enseñanzas, como persona y como profesional. He vivido de modo intenso la grandeza de las personas que tienen como misión curar y cuidar a otros. En ellos ponemos nuestra confianza y a ellos nos confiamos sin reservas. Los que nos dedicamos al oficio de la Medicina tenemos que ser conscientes de ese hecho y que no podemos defraudar a los que depositan esa fe en nosotros. Nuestros conocimientos técnicos son su gran esperanza. Merece la pena sacrificar tiempo y estudiar mucho para poder estar a la altura de lo que se merecen nuestros pacientes. Yo viví esa sensación tremendamente tranquilizadora de saber que estaba en las mejores manos.

Pero, además, la enfermedad proporciona un sentimiento profundo de vulnerabilidad y dependencia. Ahí la parte humana, el calor de los profesionales juega un papel decisivo. A veces, 
absorbidos por la importancia irrenunciable de llegar a buenos diagnósticos y tratamientos, se nos olvida la grandeza de los gestos más simples, esos que hacen sentir a los pacientes que nos importan. También eso lo he aprendido y me ha reafirmado en mi manera de entender la práctica de la medicina. Nuestros pacientes agradecen nuestra empatía y celebran cualquier gesto positivo que les hable de recuperación.

Vivir como profesional la medicina en vertical es un privilegio, vivir como paciente la medicina en horizontal puede no ser tan dolorosa, aunque se trate de un padecimiento grave, si tenemos la suerte de ser cuidados por buenos médicos, pero sobre todo por médicos buenos. Esta es una de las enseñanzas que agradezco como médico de mi experiencia como paciente de COVID-19.

(C) 2020 por los autores; Esta obra está sujeta a la licencia de Reconocimiento 4.0

Internacional de Creative Commons. Para ver una copia de esta licencia, visite http://creativecommons.org/licenses/by-nc-nd/4.0/. 